\title{
Lembaga Negara : makna, kedudukan dan relasi
}

\author{
Muhtadi \\ Bagian Hukum Tata Negara Fak. Hukum Universitas Lampung \\ email : muhtadi.1977@fh.unila.ac.id
}

\begin{abstract}
Abstrak
Tulisan ini bertujuan untuk mengetahui makna lembaga negara, kedudukan dan relasi antar lembaga negara menurut UUD Tahun 1945. Menggunakan data kepustakaan disimpulkan bahwa, pertama lembaga negara merupakan organisasi pemerintahan yang menjalankan fungsi-fungsi kenegaraan, kedua lembaga negara dapat dibentuk oleh konstitusi, Undang-undang atau peraturan perundangundangan yang lebih rendah, ketiga, lembaga negara berkedudukan di pusat pemerintahan dan dapat pula di daerah, keempat, Fungsi dan wewenang dapat menentukan kedudukan lembaga negara, sehingga terdapat kelompok lembaga negara utama (main state organt) serta lembaga negara bantu (auxiliary organt), dan kelima, relasi antar lembaga negara dapat bersifat hirarkis struktural sebagaimana doktrin pembagian kekuasaan semasa UUD 1945 sebelum perubahan, dan dapat pula secara flat, horizontal yang berada dalam kesederajatan, dan berbeda karena wewenang belaka.
\end{abstract}

\section{Kata kunci : Lembaga negara, kedudukan dan relasi}

\section{Pendahuluan}

Sebagai organisasi jabatan (ambtenorganisatie), ${ }^{1} \quad$ atau kekuasaan, ${ }^{2}$ negara memiliki alat-alat kelengkapan (Die Staatsorgane). ${ }^{3}$ Menurut Bagir Manan, dalam pengertian ketatanegaraan lembaga negara atau alat-alat perlengkapan negara hanya terbatas pada organ negara yang menjadi unsur organisasi negara yang bertindak untuk dan atas nama negara, ${ }^{4}$ yang

1 Padmo Wahjono, Negara Republik Indonesia, Rajawali Pers, Jakarta, 1995, hlm. 45, dan hlm. 60.

2 Sri Soemantri, M, Ketetapan $\operatorname{MPR}(S)$ Sebagai Salah Satu Sumber Hukum Tata Negara, Remadja Karya CV, Bandung, hlm. 1.

${ }^{3}$ Teuku Amir Hamzah,, dkk, Ilmu Negara; Kuliah-kuliah Padmo Wahjono Pada Fakultas Hukum UI Jakarta,Indo Hill Co, Jakarta, 1996, hlm. 48.

${ }^{4}$ Bagir Manan, Hubungan Ketatanegaraan Mahkamah Agung dan Mahkamah Konstitusi dengan Komisi Yudisial (Suatu menentukan atau membentuk kehendak-kemauan negara (staatswil) serta yang ditugaskan oleh hukum dasar untuk melaksanakannya, ${ }^{5}$ sehingga disebut sebagai penyelenggara negara. ${ }^{6}$ Sedangkan dari hubungan antar lembaga tersebut melahirkan hubungan ketatanegaraan (staatsrechtelijk), tetapi dilain pihak dapat pula lebih bersifat administratif (administratief rechtelijk). ${ }^{7}$ Untuk mengetahui apakah suatu lembaga bertindak untuk dan atas nama negara atau sebaliknya, lanjut Bagir, ditentukan oleh tugas dan wewenang yang terdapat dalam aturan substantif

Pertanyaan?), Varia Peradilan Majalah Hukum Tahun ke XXI Nomor 244, Maret, IKAHI, Jakarta, 2006, hlm. 5.

${ }^{5}$ Padmo Wahjono, Negara..., Op.Cit., hlm. 60.

6 Bagir Manan, Hubungan Ketatanegaraan..., Op.Cit., hlm. 4.

${ }^{7}$ Ibid. 
lembaga dimaksud. ${ }^{8}$ Demikian pula, meskipun secara faktual melaksanakan fungsi kenegaraan, tetapi secara prinsip apabila tugas dan wewenang organ tersebut merupakan pelimpahan dari pemegang kewenangan asli (original power), maka hubungan kelembagaan lebih bersifat derivatif. ${ }^{9}$ Dengan pendekatan lain, lembaga tersebut sekedar menjalankan tugas dan wewenang tertentu dari alat perlengkapan negara yang asli, sehingga tidak dapat dikategorikan sebagai lembaga negara.

\section{Perkembangan negara}

lembaga

Secara klasik, alat perlengkapan negara dalam fungsinya sebagaimana dimaksud doktrin trias politika dengan variasinya $^{10}$ terbagi dalam tiga cabang kekuasaan negara yang terpisah karena fungsi atau wewenangnya, atau catur-praja sebagaimana dimaksud C. van Vallenhoven yang meliputi (i) fungsi regeling (pengaturan), (ii) fungsi bestuur (penyelenggaraan pemerintahan), (iii) fungsi rechtsspraak (peradilan), dan (iv) fungsi politie (ketertiban dan keamanan). ${ }^{11}$ Serta dwi praja (dichotomy) yang meliputi pembuat kebijkan (policy making) dan pelaksana kebijakan (policy executing). ${ }^{12}$ Apabila dikaitkan dengan yuridis ketatanegaraan, menurut Padmo Wahjono persoalan

${ }^{8} \mathrm{Ibd}$., hlm. 5.

${ }^{9}$ Ibid.

${ }^{10}$ Padmo Wahjono, Negara..., Op.Cit.

11 Jimly Asshiddiqie, Perkembangan \& Konsolidasi..., Op.Cit., hlm. 32.

12 Ibid., Padmo Wahjono, Negara..., Op.Cit., hlm. 60. alat perlengkapan negara tersebut meliputi bentuk, susunan, tugas, wewenang, dan bagaimana pembentukannya. ${ }^{13}$

Meskipun demikian, alat perlengkapan negara sebagaimana dimaksud doktrin trias politika dalam negara hukum modern kekinian menurut Jimly Asshiddiqie sudah tidak relevan, dan ditinggalkan, sehingga pengertian organ atau lembaga negara setidaknya mencakup lima hal :

Pertama,... setiap individu yang menjalankan fungsi lawcreating dan law-applying. Kedua,... individu yang menjalankan fungsi law-creating atau law-applying dan juga mempunyai posisi sebagai atau dalam struktur jabatan kenegaraan, atau jabatan pemerintahan. Ketiga,... badan atau organisasi yang menjalankan fungsi law-creating dan/atau law-applying dalam kerangka struktur dan sistem ketatanegaraan atau pemerintahan. Termasuk di dalamnya lembaga negara yang dibentuk dengan UUD, UU, Peraturan Presiden, ataupun oleh keputusan-keputusan yang tingkatannya lebih rendah, baik di tingkat pusat ataupun di daerah. Keempat, ... lembaga-lembaga negara yang dibentuk berdasarkan UUD, UU, atau oleh peraturan yang lebih rendah. ... mencakup pula lembaga tingkat pusat dan lembaga negara tingkat daerah, dan kelima adalah lembaga negara tersendiri, yang kewenangannya ditentukan secara konstitusional dalam UUD sehingga dapat disebut sebagai lembaga negara tinggi, atau dapat disebut sebagai alat-alat

${ }^{13}$ Ibid., hlm. 60-61. 
perlengkapan negara yang utama (main organs). ${ }^{14}$

Disamping pendekatan tersebut, kelembagaan negara menurut Jimly Asshiddiqie dapat dilihat dengan teori tentang norma sumber legitimasi, yaitu:

Apa bentuk norma hukum yang menjadi sumber atau yang memberikan kewenangan kepada lembaga negara itu berkait dengan siapa yang merupakan sumber atau pemberi kewenangan terhadap lembaga negara yang bersangkutan.

Berdasarkan teori dimaksud, lembaga negara dikelompokkan menjadi lembaga negara di tingkat pusat $^{16}$ dan lembaga daerah. ${ }^{17}$ Adapun lembaga negara ditingkat pusat dikategorikan menjadi empat kelompok, yaitu :

1) Lembaga yang dibentuk
berdasarkan UUD yang diatur

14 Jimly Asshiddiqie, Perkembangan \& Konsolidasi..., Op.Cit., hlm. 40-42.

${ }^{15}$ Ibid., hlm. 50.

${ }^{16}$ Ibid.

17 Ibid., hlm. 53-54. Lembaga-lembaga daerah tersebut adalah : 1) Dibentuk UUD, UU, Peraturan Pemerintah atau Peraturan Presiden yang anggotanya diangkat dengan Keputusan Presiden; 2) Dibentuk dengan Peraturan Pusat atau Peraturan Daerah Provinsi dan anggotanya ditetapkan dengan Keputusan Presiden atau Pejabat Pusat; 3) Kewenangannya diatur dalam Peraturan Daerah Provinsi dan pengangkatan anggotanya dilakukan dengan Keputusan Gubernur; 4) Dibentuk berdasarkan Peraturan Gubernur yang pengangkatan anggotanya ditetapkan dengan Keputusan Gubernur; 5) Dibentuk berdasarkan Peraturan Gubernur yang pengangkatan anggotanya ditetapkan Keputusan Bupati atau Walikota; 6) Dibentuk dengan Peraturan Daerah Kabupaten/Kota yang pengangkatan anggotanya dengan Keputusan Bupati/Walikota; dan 7) Dibentuk dengan Peraturan Bupati/Walikota yang anggotanya ditetapkan dengan Keputusan Bupati/Walikota. dan ditentukan lebih lanjut dalam atau dengan UU, Peraturan Pemerintah, Peraturan Presiden, dan Keputusan Presiden.

2) Lembaga yang dibentuk berdasarkan undang-undang yang diatur dan ditentukan lebih lanjut dalam atau dengan Peraturan Pemerintah, Peraturan Presiden, dan Keputusan Presiden.

3) Lembaga yang dibentuk berdasarkan Peraturan Pemerintah atau Peraturan Presiden yang ditentukan lebih lanjut Keputusan Presiden.

4) Lembaga yang dibentuk berdasarkan Peraturan Menteri yang ditentukan lebih lanjut dengan Keputusan Menteri atau keputusan pejabat di bawah Menteri. ${ }^{18}$

\section{Pemisahan Kekuasaan (separation of power) atau Pembagian Kekuasaan (distribution atau division of power) dan Prinsip Saling Imbang, Saling Kontrol (Checks and balances).}

Teori pemisahan kekuasaan (separation of power) atau pembagian kekuasaan (distribution atau division of power) pada prinsipnya merupakan anti-tesa dari kemustahilan penerapan paham kedaulatan negara dari Jean Bodin (1530-1596) dan kedaulatan raja dari Thomas Hobbes. Kedaulatan menurut Bodin diartikan sebagai summa in cives at subditod legibusque soluta potestas (kekuasaan tertinggi yang mengatasi warga negara, anak buah dan

${ }^{18}$ Ibid., hlm. 50-51. 
undang-undang). Sedangkan Hobbes menempatkan raja sebagai sentral segala kekuasaan, dan karenanya ia menjadi absolut, mutlak kehendaknya, dan rakyat menjadi bagian kekuasaan. ${ }^{19}$ Pandangan Bodin selanjutnya dikembangkan Jean Jacques Reousseau (17121778), John Austin, dan Jeremy Bentham, namun menurut Montesquieu adalah mitos belaka. ${ }^{20}$ Sedangkan kemutlakan raja yang diagungkan Hobbes, oleh Locke disebut sebagai pemikiran ceroboh yang akan melahirkan tindakan yang dapat merampas hak hidup, kemerdekaan dan hak milik yang melahirkan status politik sebagai hak-hak alamiah manusia. ${ }^{21}$ Untuk melindungi kepentingan itu, menurut Locke kekuasaan negara harus terpencar dan terpisah dalam tiga organ. Yaitu, kekuasaan pembuat undang-undang (legislatif), kekuasaan menjalankan dan mempertahankan undang-undang, termasuk melakukan peradilan (eksekutif), dan kekuasaan federatif, yang menjalankan kekuasaan selebihnya dari dua cabang sebelumnya. $^{22}$

Gagasan pemisahan kekuasaan itu sendiri menurut Locke adalah :

"The Three organs of state must not get into one hand... it may be too great a temptation to human frailty, apt to graps at power, for the same who have the power making laws, to have also in their the power to execute them, whereby they may exempt themselves from obedience to

19 Jimly Asshiddiqie, Konsitusi dan Konstitusionalisme..., Op.Cit., hal. 101.

${ }^{20}$ Ibid., hlm. 104.

${ }^{21}$ Ni'matul Huda, Lembaga Negara Dalam Masa Transisi Demokrasi, UII Press, Yogyakarta, 2007, hlm. 66.

${ }^{22}$ Ibid., hlm. 69-70. the law make, and suit the law, both in its making and execution, to their own private advantage". ${ }^{23}$

Oleh Ni'matul Huda, penggalan anak kalimat ... it may be too great ...advantage..., diterjemahkan sebagai :

"...akan menjadi cobaan yang sangat berat bagi kelembagan manusia untuk memegang kekuasaan kalau orang-orang yang memiliki kekuasaan untuk membuat hukum, juga memiliki kekuasaan untuk melaksanakannya, karena mereka akan mengecualikan diri mereka dari ketaatan mematuhi hukum yang mereka buat sendiri, dan mereka akan mencoba membuat dan melaksanakan hukum yang melayani kepentingan pribadi mereka dan melawan kepentingan masyarakat pada umumnya, sehingga bertentangan dengan tujuan dari masyarakat dan pemerintahan itu sendiri." 24

Kekuasaan negara yang terpusat pada satu organ tunggal dengan menggabungkan fungsifungsi kenegaraan memiliki potensi lebih besar untuk disalahgunakan (abuse de droit, atau mesbruik van recht), atau dilaksanakan dengan sewenang-wenang (arbitrary, atau willekeur), atau dilaksanakan secara melampaui kewenangannya (detournement de pouvoir). ${ }^{25}$ Sehingga pemencaran kekuasaan

23 Michael T. Molan, Constitutional Law:The Machinery of Government, $4^{\text {th }}$ Edition, Old Bailey Press, London, 2003, hlm. 63-64.

${ }^{24}$ Ni'matul Huda, Op.Cit., hlm. 67.

25 Bagir Manan, Kedudukan Penegak Hukum,....Op.Cit., hlm. 9, lihat juga Yan Pramudya PUSPA, Kamus Hukum, Aneka Ilmu, Semarang, 1977, hlm. 306. Lihat juga Marjanne Termorshuizen, Kamus hukum Belanda-Indonesia, Jambatan, Jakarta, 1993, hlm. 98 dan hlm.540. 
negara ke dalam cabang-cabang yang saling terpisah dan kesederajatan kedudukan satu sama lainnya merupakan pendekatan yang diharapkan dapat menghilangkan, atau setidaknya mengurangi nafsu kekuasaan yang cenderung dapat disalahgunakan pribadi-pribadi yang kebetulan sedang memangku jabatan tersebut, sehingga dapat dicegah dan ditanggulangi dengan sebaikbaiknya. $^{26}$ Atas dasar demikian, Montesquieu yang mengembangkan pandangan Locke melakukan pemisahan kekuasaan berdasarkan fungsi organ dalam negara. Akan tetapi dibandingkan dengan Locke yang menggabungkan kekuasaan peradilan dalam kekuasaan eksekutif, maka Montesquieu yang memiliki latar belakang sebagai hakim dan merasakan kuatnya intervensi eksekutif, memandang pelaksana yudisial harus dipisahkan secara tegas dari eksekutif, tetapi menggabungkan kekuasaan federatif sebagai bagian wewenang eksekutif, sehingga organ federatif tidak berdiri sendiri.

Menurut Jimly Asshiddiqie gagasan pemisahan kekuasaan yang terpencar dalam doktrin trias politika Montesquieu adalah bahwa :

"... In every government, there are three sorts of powers: the legislative; the executive in resfect to things dependent on the law of nations; and the executive in regard to materrs that depend on civil law. $^{27}$

26 Jimly Asshiddiqie, Struktur Ketatanegaraan Indonesia Setelah..., Op.Cit., hal. 12, lihat juga Jimly Asshiddiqie, Konstitusi dan Konstitusionalisme..., Op.Cit., hlm. 59.

27 Jimly Asshiddiqie, Perkembangan dan Konsolidasi Lembaga Negara Pasca Reformasi, Konstitusi Press, Jakarta, 2006,
Adapun dimaksud kekuasaan yudisial (la puissance de juger, atau judicial power) dalam pandangan Montesquieu tersebut, menurut Lee Cameron McDonald tidak lain adalah the executive in regard to matters that depend on the civil law, yaitu cabang kekuasaan eksekutif yang berhubungan dengan penerapan hukum sipil. ${ }^{28}$

Namun demikian, doktrin pemisahan kekuasaan yang benarbenar bersifat multak dalam perkembangan sistem pemerintahan negara tidaklah memiliki keseragaman corak, dan bahkan kemudian tidak menjadi absolutisme, dalam kelembagaan, maupun kewenangannya, melainkan bergantung kepada praktik politik, kebiasaan dan prinsip-prinsip hukum negara bersangkutan. Kenyataan ini oleh John Marshal nyatakan sebagai :

"The phrase 'separation of power' is, however, one of the most confusing in the vocabulary of political and constitutional thougt. It has been used with variying implications by historian and political scientist".

(Ungkapan pemisahan kekuasaan merupakan salah satu yang paling membingungkan di dalam kosakata pemikiran politik dan konstitusional. Ungkapan pemisahan kekuasaan tersebut telah digunakan dengan berbagai implikasi oleh para sejarawan dan ilmuwan politik). ${ }^{29}$

Disamping itu, gagasan pemisahan kekuasaan sejak semula disadari dapat menciptakan arogansi masing-masing cabang kekuasaan, sehingga untuk menghindari tirani

hlm. 35, lihat juga Michael T. Molan, Constitutional Law.., Op.Cit. hlm. 64.

${ }^{28} \mathrm{Ibid}$.

29 Ni'matul Huda, Lembaga Negara..., Op.Cit., hlm. 65. 
kelembagaan, ataupun pengisolasian antara cabang negara, disertai prinsip pembatasan yang menjamin bahwa diantara cabang-cabang kekuasaan tidak saling melampaui wewenangnya melalui sistem pengawasan dan keseimbangan (checks and balances). ${ }^{30}$

Menurut L. Berman sebagaimana dikutip Hendra Nurtjahjo, doktrin trias politika yang menjalankan checks and balances adalah :

"System that ensure that for every power in government there is an equal and opposite power placed in separate branch to restrain that force ... checks and balances are the constitutional controls whereby separate branches of government have limiting powers over each others so that no branch will become supreme."

"Sistem yang memastikan bahwa setiap kekuasaan di pemerintahan adalah sederajat dan oposisi berada pada cabang terpisah untuk mengendalikan kekuasaan itu.... saling mengawasi dan mengimbangi merupakan kontrol konstitutional dimana cabang yang terpisah dari pemerintah mempunyai kekuasaan terbatas melingkupi kekuasaan lainnya sehingga tidak akan terdapat cabang kekuasaan tertinggi." 31

Dengan demikian, separation of power lebih bersifat horizontal yang memisahkan cabang-cabang

30 Miriam Budiardjo, Dasar-dasar Ilmu Politik, Gramedia, Jakarta, 2002, hlm. 153.

31 Hendra Nurtjahjo, Ilmu Negara; Pengembangan Teori Bernegara dan Suplemen, RajaGrafindo Persada, Jakarta, 2005, hlm. 72. kekuasaan negara dalam kesederajatan kedudukan dan saling mengimbangi (checks and balances), sehingga masing-masing cabang kekuasaan tidak saling menggerogoti ataupun terisolasi dari yang lain. ${ }^{32}$ Sedangkan distribution atau division of power bersifat vertikal yang membagi-bagi kekuasaan negara kepada organ tinggi negara dibawah pemegang kedaulatan tertinggi. ${ }^{33}$

Perkembangan negara hukum dari klasik ke modern (klassiekerechsstaat ke modernrechsstaat, dari Nachtwakerstaat menuju welfaarstaat) dengan menempatkan negara sebagai penanggungjawab umum kesejahteraan warganya merupakan salah satu faktor yang menjadikan penerapan trias politika oleh berbagai negara tidak lebih sebagai doktrin dasar dalam penyelenggaraan negara yang tidak terkumpul pada satu organ belaka. Dengan demikian, menjadi conditio sine quo non perkembangan alat perlengkapan negara dengan pertumbuhan negara yang semakin kompleks, sehingga organ-organ negara di-create melalui konstitusi -dan peraturan perundangundangan di bawahnya- tidak lagi terbatas pada doktrin trias politika, melainkan kemudian muncul dan berkembang alat perlengkapan negara lainnya baik dalam wujud sebagai institusi tambahan (state auxiliuries), badan-badan

\footnotetext{
${ }^{32}$ Ranny Emmilia, Mekanisme Pengawasan dan Pengimbangan dalam Hubungan Antar Lembaga Tinggi Negara,dalam Eko Bambang Subiantoro, Indah Nataprawira, dan Suryo Aribowo (editor), Menggagas Ulang Prinsip-prinsip Lembaga Kepresidenan, CPPS Paramadina dan Partnership for Governance Reforma in Indonesia, Jakarta, 2002, hlm. 58.

33 Jimly Asshiddiqie, Konstitusi dan Konstitusionalisme..., Op.Cit., hlm. 133.
} 
independen (independen state bodies atau self regulatory bodies), state enterprise dan lain-lain, ${ }^{34}$ yang sekaligus menegaskan ketidakrelevanan kekinian pemisahan secara ekslusif dalam salah satu dari ketiga fungsi kekuasaan negara. ${ }^{35}$

\section{Simpulan}

1. Lembaga negara merupakan organisasi pemerintahan yang menjalankan fungsi-fungsi kenegaraan;

2. Lembaga negara dapat dibentuk oleh konstitusi, Undang-undang atau peraturan perundnagundangan yang lebih rendah;

3. Lembaga negara berkedudukan di pusat pemerintahan dan dapat pula di daerah.

4. Fungsi dan wewenang dapat menentukan kedudukan lembaga negara, sehingga terdapat kelompok lembaga negara utama (main state organt) serta lembaga negara bantu (auxiliary organt);

5. Relasi antar lembaga negara dapat bersifat hirarkis strktural sebagaimana doktrin pembagian kekuasaan semasa UUD 1945 sebelum perubahan, dan dapat pula secara flat, horizontal yang berada dalam kesederajatan, dan berbeda karena wewenang belaka.

\section{Daftar Pustaka}

Padmo Wahjono, 1995, Negara Republik Indonesia, Jakarta: Rajawali Pers.

Sri Soemantri m, 1987, Ketetapan MPR(S) Sebagai Salah Satu

${ }^{34}$ Hendra Nurtjahjo,Op.Cit., hlm. 63.

35 Jimly Asshidiqie, Perkembangan dan Konsolidasi... Op.Cit., hlm. ix.
Sumber Hukum Tata Negara, Remadja Karya CV, Bandung ${ }^{1}$

Teuku Amir Hamzah, dkk, 1996, Ilmu Negara; Kuliah-kuliah Padmo Wahjono Pada Fakultas Hukum UI Jakarta, Indo Hill Co, Jakarta

Varia Peradilan Majalah Hukum Tahun ke XXI Nomor 244, Maret, 2006, IKAHI, Jakarta.

Ni'matul Huda, Lembaga Negara Dalam Masa Transisi Demokrasi, UII Press, Yogyakarta, 2007, hlm. 66.

Michael T. Molan, 2003, Constitutional Law:The Machinery of Government, $4^{\text {th }}$ Edition, Old Bailey Press, London

Jimly Asshiddiqie, 2006, Perkembangan dan Konsolidasi Lembaga Negara Pasca Reformasi, Konstitusi Press, Jakarta 2005. Format Kelembagaan Negara dan Pergeseran Kekuasaan dalam UUD 1945, UII Press, Yogyakarta.

Miriam Budiardjo, 2002, Dasardasar Ilmu Politik, Gramedia, Jakarta

Hendra Nurtjahjo, 2005, Ilmu Negara; Pengembangan Teori Bernegara dan Suplemen, RajaGrafindo Persada, Jakarta

Suryo Aribowo (editor), Menggagas Ulang Prinsip-prinsip Lembaga Kepresidenan, CPPS Paramadina dan Partnership for Governance Reforma in Indonesia, Jakarta. 
